\section{Manure and Soil Zinc Application to 'Wichita' Pecan Trees Growing Under Alkaline Conditions}

\author{
Humberto Núñez-Moreno \\ Instituto Nacional de Investigaciones Forestales y Agropecuarias, Carr. \\ Bahia de Kino Km 12.6, Hermosillo, Sonora, México, 83220
}

\begin{abstract}
James L. Walworth ${ }^{1}$ and Andrew P. Pond
Department of Soil, Water and Environmental Science, University of Arizona, 429 Shantz Building \#38, 1177 E. Fourth Street, Tucson, AZ 85721
\end{abstract}

Additional index words. Carya illinoinensis, yield efficiency, nut quality, yield, leaf mineral composition

\begin{abstract}
The effect of cattle manure or combined manure and zinc ( $\mathrm{Zn})$ application on Zn uptake, mineral composition, and yield and nut quality in pecan trees [Carya illinoinensis (Wangenh.) C. Koch] was evaluated. In 2006, treatments evaluated were: manure (12 ton/ha; $\mathrm{M}$ ), manure plus $\mathrm{Zn}\left(12\right.$ ton/ha plus $129 \mathrm{~kg} \mathrm{Zn/ha} \mathrm{as} \mathrm{ZnSO}_{4}$; MZ), and an untreated control. During 2007, two more treatments were added with doubled manure and $Z n$ rates. New treatments were manure $2 \times(24$ ton/ha; M2) and manure $2 \times$ plus $\mathrm{Zn} 2 \times\left(24\right.$ ton/ha plus $258 \mathrm{~kg} \mathrm{Zn}$ as $\left.\mathrm{ZnSO}_{4} ; \mathrm{M2Z2}\right)$. Manure was broadcast on the soil in a $2.5-\mathrm{m}$ wide band $2 \mathrm{~m}$ from the trunk. Zinc sulfate was broadcast over the manure, and then manure and $\mathrm{Zn}$ were disked into the top $10 \mathrm{~cm}$ of soil. In 2008, in five of nine sampling dates, significant treatment effects were detected on leaf $\mathrm{Zn}$ concentrations. On all of the dates, M2Z2 had the highest foliar Zn levels. During the Summer 2008 (17 July) foliar $\mathrm{Zn}$ in M2Z2, treatment reached $66 \mu \mathrm{g} \cdot \mathrm{g}^{-1}$; the control treatment level was 45 $\mu \mathrm{g} \cdot \mathrm{g}^{-1}$. Nut yields were higher in treatments receiving manure, with or without $\mathrm{Zn}$ in the first year, and highest in the untreated control the second year. No differences were observed in trunk growth, leaf area, leaf weight, or nut growth. Kernel percentages were over 61.4 in the 3 years of study in all treatments. Largest differences among treatments in nut size were found in 2007; nut weight in the control treatment was 7.5 g per nut and in $M$ was 8.0 g per nut. Nut weight was smaller during 2008 when nut yield was high, and the untreated control nuts were smaller than those from treated trees. The manure and manure plus $\mathrm{Zn}$ treatments increased foliar $\mathrm{Zn}$ levels in pecan trees after 3 years of annual applications. In 2008, significant differences in leaflet $\mathrm{Zn}$ concentration among treatments were detected with M2Z2 having the highest concentrations.
\end{abstract}

Pecan trees growing in alkaline and calcareous soils are prone to zinc $(\mathrm{Zn})$ deficiency (Malstrom and Fenn, 1981; Smith et al., 1980). Soluble Zn compounds such as $\mathrm{Zn}$ sulfate applied to alkaline soil react with hydroxides and carbonates and are converted to compounds unavailable to plants (Essington, 2003; Lindsay, 1972; Sadiq, 1991; Udo et al., 1970). Acidification using large quantities of strong acids such as sulfuric acid can increase $\mathrm{Zn}$ uptake by pecan (Fenn et al., 1990). Acid-forming compounds such as sulfur (S) and organic matter can increase $\mathrm{Zn}$ availability (Essington, 2003). Humic acids can also complex metals, including $\mathrm{Zn}$, increasing mobility and solubility in calcareous soil (Bunluesin et al., 2006; Chien et al., 2006; Ozkutlu et al., 2006). Addition of manure, S, and $\mathrm{Zn}$ can decrease rosette symptoms caused by $\mathrm{Zn}$

Received for publication 14 May 2009. Accepted for publication 22 July 2009 .

${ }^{1}$ To whom reprint requests should be addressed; e-mailWalworth@ag.arizona.edu. deficiency in pecans growing in heavytextured alkaline soils (Alben and Hammer, 1944). Fertilization of alkaline soils with $\mathrm{Zn}$, in combination with sulfuric acid, was evaluated by acidifying a shallow trench making up less than $1 \%$ of the effective root zone of a mature Texas pecan trees by applying a mixture of $9 \mathrm{~kg} \mathrm{ZnSO}_{4}$ and $113 \mathrm{~L}$ of $36 \mathrm{~N}$ $\mathrm{H}_{2} \mathrm{SO}_{4} /$ tree. Leaf $\mathrm{Zn}$ did not change in the first 3 years, but 4 years after application, leaves of the treated trees contained $54 \mu \mathrm{g} \cdot \mathrm{g}^{-1}$ $\mathrm{Zn}$ versus $39 \mu \mathrm{g} \cdot \mathrm{g}^{-1}$ in the untreated control. After 9 years, leaf $\mathrm{Zn}$ levels were 58 and 45 $\mu \mathrm{g} \cdot \mathrm{g}^{-1}$ for treated and untreated trees, respectively, and $56 \mu \mathrm{g} \cdot \mathrm{g}^{-1}$ in trees receiving $\mathrm{ZnSO}_{4}$ alone. Soil $\mathrm{pH}$ was decreased to a depth of $60 \mathrm{~cm}$; however, roots did not grow into the acidified soil, proliferating instead at the interface of the acidified and calcareous soil (Fenn et al., 1990).

Increased soil organic carbon increased desert soils in Nigeria; DTPA-extractable Zn rose $0.17 \mathrm{mg} \cdot \mathrm{kg}^{-1}$ with each percent increase in soil organic matter (Agbenin, 2003). It is not surprising then that addition of organic levels of DTPA-extractable $\mathrm{Zn}$ in tropical matter to soil can increase $\mathrm{Zn}$ levels and plant growth in annual plants such as rice, sorghum, and soybean (Battacharyya. et al., 2006; Pinto et al., 2004; Warwick et al., 1998; Zheljazkov and Warman, 2004). Even without incorporation into the soil, use of organic mulch at planting increased the trunk cross-sectional area (TCSA) in young 'Desirable' pecan trees. After 3 years, TCSA was $31 \mathrm{~cm}^{2}$ in untreated trees versus $39 \mathrm{~cm}^{2}$ in trees with 10 $\mathrm{cm}$ of mulch applied to the soil surface (Foshee et al., 1996). In another study, incorporation of pecan pruning wood chips into the soil improved soil tilth and aggregation and increased volumetric water content $20 \mathrm{~d}$ after irrigation (Tahboub et al., 2008) while not affecting nitrogen, phosphorus, or potassium availability (Tahboub et al., 2007).

Increased use of animal manure in pecan orchards has recently accompanied a shift toward "organic" production. The purpose of the manure applications is primarily to supply nitrogen in this production system. The relatively large quantities of manure used for this purpose $\left(\approx 5\right.$ to $\left.12 \mathrm{Mt} \cdot \mathrm{ha}^{-1}\right)$ might reasonably be expected to have an impact on levels of soil organic matter and metal solubility and bioavailability. Manure fortified with supplemental $\mathrm{Zn}$ might provide additional available $\mathrm{Zn}$ for trees growing in calcareous soils.

Zinc uptake and pecan tree performance were studied after the application of manure alone or in combination with $\mathrm{Zn}$ sulfate. The purpose of this study was to determine the effect of the addition of manure on $\mathrm{Zn}$ uptake, growth, yield, and nut quality of pecan trees growing under alkaline and calcareous conditions and to ascertain whether these effects can be enhanced by providing extra $\mathrm{Zn}$ with applied manure.

\section{Materials and Methods}

A field study was conducted in a commercial pecan orchard in southeast Arizona (lat. $31^{\circ} 55^{\prime} 01.25^{\prime \prime} \mathrm{N}$, long. $110^{\circ} 57^{\prime} 27.56^{\prime \prime}$, elev. $844 \mathrm{~m}$ ) on 'Wichita' pecan trees (7 years old) from May 2005 to Dec. 2008. The alluvial soil in the orchard is a calcareous Pima clay loam with a soil $\mathrm{pH}$ of 7.6 (fine silty, mixed, thermic Typic torrifluvents). This site is semiarid with a mean annual soil temperature from 15 to $22^{\circ} \mathrm{C}$ and the area has a mean annual precipitation between 25 and $40 \mathrm{~cm}$ (Hendricks, 1985). Table 1 presents general soil characteristics of the orchard site at $0-$ to $30-\mathrm{cm}$ depth. The soil is typical of many southwestern U.S. soils and therefore many regional pecan orchards. Trees are planted in a square design and the space between trees is $9.15 \mathrm{~m}$. Mowing was used to keep the soil clean of weeds during growing seasons. Trees were flood-irrigated twice each month from April to October. A total of $1.50 \mathrm{~m}$ of water depth was applied each year. Standard chemical methods were initially used to control aphids, but in 2007, the orchard was converted to "organic" production and pest control methods were changed accordingly. During the winter of 
2006-2007, trees in the buffer rows between experimental plot rows were mechanically hedge-pruned. In the winter of 2007-2008, trees in treatment rows were also hedged. Trees were hedged $3 \mathrm{~m}$ from each side of the trunk and $9 \mathrm{~m}$ high. Lateral hedge-pruning had an inclination of $5^{\circ}$ from the vertical toward the trunk with the top pruned at an angle of $160^{\circ}$.

In 2006, treatments evaluated were: manure (a blend of cattle and horse manure at 12 ton/ha) (M1), manure plus $\mathrm{Zn}$ (12 ton/ha of manure plus $129 \mathrm{~kg}$ of $\mathrm{Zn} / \mathrm{ha}$ as $\mathrm{ZnSO}_{4}$ ) (M1Z1), and an untreated control. The manure application rate is that used commercially to supply nitrogen in this orchard. None of the plots were sprayed with $\mathrm{Zn}$ during the study. Two additional treatments were to have received a urea application instead of manure, but were left untreated in 2006 because the block was converted to organic production. Instead, these plots were used to evaluate two more treatments with doubled rates of manure and manure plus $\mathrm{Zn}$ in 2007: 24 ton/ha of manure (M2) and 24 ton manure/ ha plus $258 \mathrm{~kg} \mathrm{Zn} / \mathrm{ha}$ as $\mathrm{ZnSO}_{4}$ (M2Z2).

Manure was broadcast on the soil in a 2.5-m wide band beginning $2 \mathrm{~m}$ from the trunk. Zinc sulfate was broadcast over the manure. All plots were disked to mix the top $10 \mathrm{~cm}$ of soil. Manure had a $\mathrm{pH}$ of 7.8 and an electrical conductivity of 4.0 and contained $\approx 0.84 \%$ nitrogen, $0.18 \% \mathrm{P}_{2} \mathrm{O}_{5}$, and $1.19 \% \mathrm{~K}_{2} \mathrm{O}$. Treatments were replicated four times in a randomized complete block design. Each experimental plot consisted of one row containing 15 trees ( $\mathrm{n}=12$ in 2006; $\mathrm{n}=20$ in subsequent years). Leaf samples and growth measurements were collected from the 11 central trees in each plot row. Experimental plot rows were each separated by one buffer row. Data were analyzed using analysis of variance with mean separation with Tukey's test (SAS Version 9.1; SAS Institute, Cary, NC).

Twenty-four middle leaflet pairs located in the middle of the current year's shoot growth were collected every 2 or 3 weeks from May to October for $\mathrm{Zn}$ analysis. These samples were collected from the branches on the lower part of the trees that could be reached from the ground. Leaflet samples collected in late July were used for complete elemental analysis. Leaves were washed using the following routine: washed in phosphatefree soap, rinsed in tap water, rinsed in distilled water, and rinsed three times in deionized water. Leaf samples were dried at $70{ }^{\circ} \mathrm{C}$, weighed, and then ground in a mortar. During 2008, a rinse with hydrochloric acid $(1 \% \mathrm{v} / \mathrm{v})$ was added between the distilled water and deionized water rinses. Leaf tissue was ashed at $500{ }^{\circ} \mathrm{C}$ for $5 \mathrm{~h}$ and then dissolved in $2.2 \mathrm{~N}$ hydrochloric acid. Complete nutrient analysis was conducted on samples collected in late July or early August each year. Nitrogen was determined by Macro-Kjeldahl (Horowitz, 1980); phosphorus was determined colorimetrically (Olsen and Sommers, 1982); and potassium, calcium, magnesium, S, iron, Zn, copper, and manganese by atomic absorption spectroscopy.
Trunk circumference was measured at $20 \mathrm{~cm}$ above the ground in Feb. 2007 and Feb. 2008. Trunk cross-sectional area was calculated from these measurements. Leaflet growth and chlorophyll index were determined on a sample of 60 leaflets collected in late July or early August. Chlorophyll index was obtained using a Konica Minolta SPAD $502 \mathrm{~m}$ (Konica Minolta Sensing America Inc., Ramsey, NJ) by optical density difference at two wavelengths (650 and $940 \mathrm{~nm}$ ). Chlorophyll readings were conducted on the middle part of the leaflet. Leaflets were scanned on a flatbed scanner and leaflet area obtained using Scion Image software (Scion Corp., Frederick, MD). During late July or early August, 20 middle pairs of leaflets were collected from the top half of the trees as described previously for the bottom part of the tree to determine if leaf
$\mathrm{Zn}$, leaf area, and leaf weight in the upper half of trees were affected by treatments.

During 2006 and 2007, nut yield and quality were determined. Yield was calculated by mechanically harvesting the complete experimental row. Alternate bearing intensity (I) was determined by the ratio between the absolute difference in yield with the sum of the yields of successive years (Pearce and Dobersek-Urbanc, 1967) according to the formula:

$$
\begin{aligned}
I= & \frac{1}{n-1} *\left(\left|\frac{Y_{1}-Y_{2}}{Y_{1}+Y_{2}}\right|+\left|\frac{Y_{2}-Y_{3}}{Y_{2}+Y_{3}}\right|\right. \\
& \left.+\ldots+\left|\frac{Y_{n-1}-Y_{n}}{Y_{n-1}+Y_{n}}\right|\right)
\end{aligned}
$$

where $\mathrm{I}=$ alternate bearing intensity, $\mathrm{n}=$ total of years, and $\mathrm{Y}=$ year. Values are absolute numbers.

\begin{tabular}{|c|c|c|c|}
\hline Soil test & Method & Units & Value \\
\hline$\overline{\mathrm{pH}}$ & Saturated paste & SU & 7.5 \\
\hline Electrical conductivity & Saturated paste & $\mathrm{dS} \cdot \mathrm{m}^{-1}$ & 0.44 \\
\hline Calcium & $\mathrm{NH}_{4} \mathrm{OAc}(\mathrm{pH} 8.5)$ & $\mathrm{mg} \cdot \mathrm{kg}^{-1}$ & 4000 \\
\hline Magnesium & $\mathrm{NH}_{4} \mathrm{OAc}(\mathrm{pH} 8.5)$ & $\mathrm{mg} \cdot \mathrm{kg}^{-1}$ & 310 \\
\hline Potassium & $\mathrm{NH}_{4} \mathrm{OAc}(\mathrm{pH} 8.5)$ & $\mathrm{mg} \cdot \mathrm{kg}^{-1}$ & 510 \\
\hline Zinc & DTPA & $\mathrm{mg} \cdot \mathrm{kg}^{-1}$ & 3.2 \\
\hline Iron & DTPA & $\mathrm{mg} \cdot \mathrm{kg}^{-1}$ & 5.1 \\
\hline Manganese & DTPA & $\mathrm{mg} \cdot \mathrm{kg}^{-1}$ & 9.4 \\
\hline Copper & DTPA & $\mathrm{mg} \cdot \mathrm{kg}^{-1}$ & 2.4 \\
\hline Nickel & DTPA & $\mathrm{mg} \cdot \mathrm{kg}^{-1}$ & 0.12 \\
\hline $\mathrm{NO}_{3}-\mathrm{N}$ & Cd reduction & $\mathrm{mg} \cdot \mathrm{kg}^{-1}$ & 8.8 \\
\hline $\mathrm{PO}_{4}-\mathrm{P}$ & Olsen & $\mathrm{mg} \cdot \mathrm{kg}^{-1}$ & 9.0 \\
\hline $\mathrm{SO}_{4}-\mathrm{S}$ & Hot water & $\mathrm{mg} \cdot \mathrm{kg}^{-1}$ & 22 \\
\hline Boron & Hot water & $\mathrm{mg} \cdot \mathrm{kg}^{-1}$ & 0.28 \\
\hline Free lime & Effervescence & & High \\
\hline Exchangeable sodium percent & Calculated & $\%$ & 1.8 \\
\hline Cation exchange capacity & Calculated & $\mathrm{cmol}_{\mathrm{c}} \cdot \mathrm{kg}^{-1}$ & 24.3 \\
\hline
\end{tabular}

Table 1. Orchard soil characteristics at the beginning of the study.

Table 2. Effect of manure and zinc ( $\mathrm{Zn}$ ) application on foliar $\mathrm{Zn}$ concentration during the growing season in 'Wichita' pecan trees $\left(\mu \mathrm{g} \cdot \mathrm{g}^{-1}\right.$ dry weight $) .^{\mathrm{z}}$

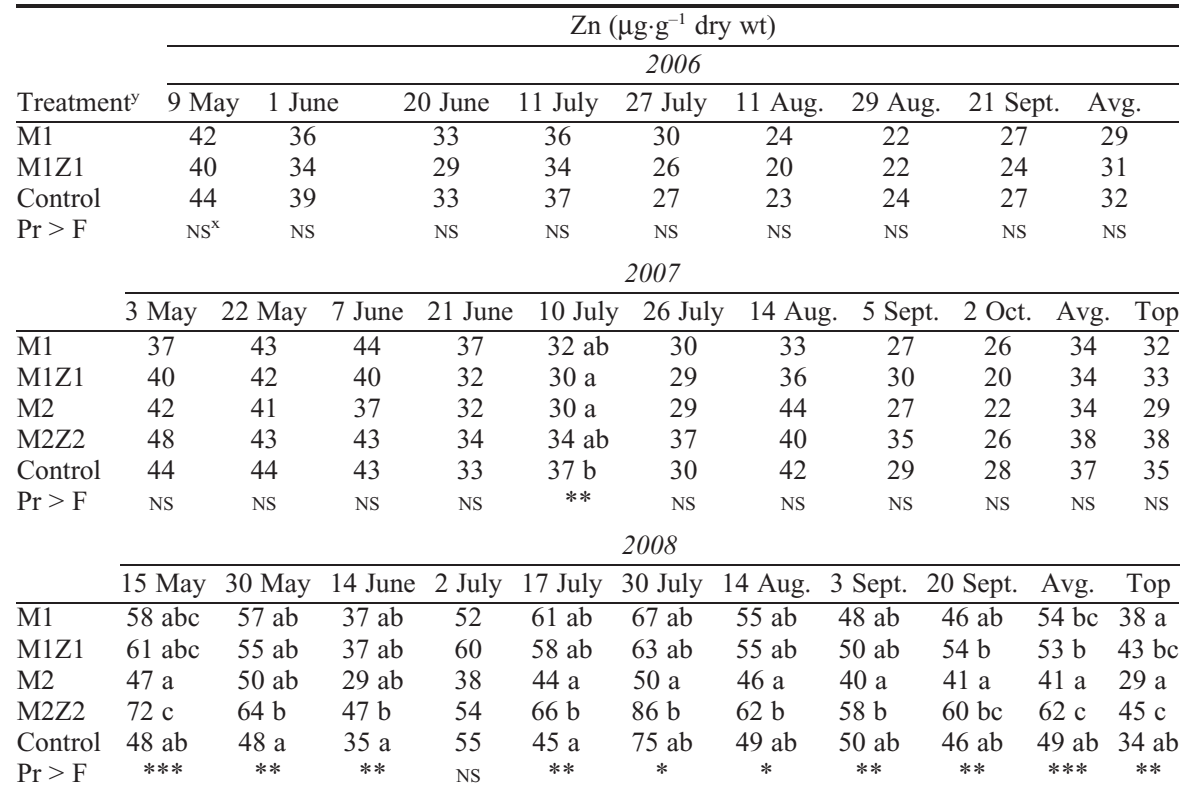

${ }^{\mathrm{z}}$ Means followed by different letters are different at $P=0.05$ through analysis of variance testing.

${ }^{\mathrm{y}} \mathrm{M} 1=$ manure $12 \mathrm{ton} / \mathrm{ha} ; \mathrm{M} 2=$ manure $24 \mathrm{ton} / \mathrm{ha} ; \mathrm{Z1}=129 \mathrm{~kg} \mathrm{Zn}$ as $\mathrm{ZnSO}_{4} ; \mathrm{Z} 2=258 \mathrm{~kg} \mathrm{Zn}$ as $\mathrm{ZnSO}_{4}$ (manure had a $\mathrm{pH}$ of 7.8 and an electrical conductivity of 4.0 and contained $\approx 0.84 \% \mathrm{~N}, 0.18 \mathrm{P}_{2} \mathrm{O}_{5}, 1.19$ $\left.\mathrm{K}_{2} \mathrm{O}\right)$.

${ }_{\mathrm{NS}}, *, * *=$ Nonsignificant, significant $(\operatorname{Pr}>\mathrm{F}=0.05)$, and highly significant $(\operatorname{Pr}>\mathrm{F}=0.01)$. 
A sample of harvested nuts was used to determine kernel percent, yield, percent of good nuts, pre-germinated nuts (viviparous), and "stick-tight" nuts. "Stick-tights" are those fruit with shucks that do not separate from the shell at maturity; the shuck remains stuck to the shell after harvest and cannot be separated completely. Yield efficiency was calculated as yield $/ \mathrm{cm}^{2}$ of TCSA. Kernel percent was determined by cracking 10 nuts from each experimental plot and separately weighing shell and kernel. Weight per nut was calculated from the number of nuts in a 1-kg sample.

\section{Results}

Leaflet $\mathrm{Zn}$ concentration was unaffected during the first year of study in 2006 (Table 2). Significant differences were found in July 2007 with the control having the highest foliar Zn level. In 2008, in eight of the nine leaf sampling dates, significant effects were detected. On all of these sampling dates, trees in the M2Z2 treatment had the highest foliar $\mathrm{Zn}$ levels. During the summer of 2008 (17 July), in this treatment, foliar $\mathrm{Zn}$ reached 66 $\mathrm{mg} \cdot \mathrm{kg}^{-1}$, whereas the control treatment had $45 \mathrm{mg} \cdot \mathrm{kg}^{-1}$. Only the M2 treatment had lower foliar $\mathrm{Zn}$ levels than the control. In 2007, no significant differences were found in foliar $\mathrm{Zn}$ between the bottom and top sections of the trees, but in 2008, leaflets from the top had significantly lower values than the bottom leaflets.

Zinc treatments did not affect TCSA, leaflet size and weight, and chlorophyll index (Table 3). Neither TCSA nor its increase in 2 consecutive years was affected by treatments.

Heavy rainfalls during 2006 prevented the use of the hydraulic lift needed to sample the top part of the trees. In 2007 and 2008, specific leaflet areas from the top and bottom parts of the trees were unaffected by manure or $\mathrm{Zn}$ applications. Chlorophyll index varied

Table 3. Effect of manure and zinc $(\mathrm{Zn})$ application on growth parameters in 'Wichita' pecan trees.

\begin{tabular}{lcccc}
\hline & 2006 & 2007 & 2008 & \\
\cline { 2 - 3 } Treatments $^{z}$ & \multicolumn{2}{c}{ Trunk } & cross-sectional area $\left(\mathrm{cm}^{2} \cdot\right.$ ha $\left.^{-1}\right)$ & Increase $(2007-2008)$ \\
\hline M1 & 387.4 & 456.8 & 514.2 & 58.3 \\
M1Z1 & 393.7 & 447.5 & 544.5 & 97.0 \\
M2 & & 417.1 & 480.7 & 63.6 \\
M2Z2 & & 403.3 & 466.5 & 63.2 \\
Control & 354.6 & 405.7 & 482.2 & 76.5 \\
Pr $>$ F & NS $^{\mathrm{y}}$ & $\mathrm{NS}$ & & NS
\end{tabular}

\begin{tabular}{|c|c|c|c|}
\hline \multicolumn{4}{|c|}{ Leaflet area bottom $\left(\mathrm{cm}^{2}\right)$} \\
\hline$\overline{\mathrm{M} 1}$ & 23.2 & 31.4 & 20.4 \\
\hline M1Z1 & 23.7 & 32.7 & 20.4 \\
\hline M2 & & 29.9 & 19.9 \\
\hline M2Z2 & & 30.0 & 20.3 \\
\hline Control & 22.4 & 30.1 & 21.8 \\
\hline
\end{tabular}

$\operatorname{Pr}>\mathrm{F}$

NS

NS

NS

Leaflet area top $\left(\mathrm{cm}^{2}\right)$

\begin{tabular}{lcc}
\hline M1 & 23.0 & 26.5 \\
M1Z1 & 22.3 & 24.3 \\
M2 & 21.9 & 24.7 \\
M2Z2 & 21.4 & 25.9 \\
Control & 20.7 & 22.5 \\
Pr $>$ F & 0.895 & 0.44
\end{tabular}

NS NS

Leaflet weight bottom $(g)$

\begin{tabular}{|c|c|c|}
\hline$\overline{\mathrm{M} 1}$ & 0253 & 0120 \\
\hline M1Z1 & 0. 275 & 0130 \\
\hline M2 & 0.247 & 0.125 \\
\hline M2Z2 & 0.235 & 0.136 \\
\hline Control & 0.265 & 0.129 \\
\hline $\operatorname{Pr}>F$ & NS & NS \\
\hline \multicolumn{3}{|c|}{ Leaflet weight top ( $g$ ) } \\
\hline$\overline{\mathrm{M} 1}$ & 0.224 & 0.223 \\
\hline M1Z1 & 0.221 & 0.208 \\
\hline M2 & 0.217 & 0.212 \\
\hline M2Z2 & 0.217 & 0.234 \\
\hline Control & 0.193 & 0.195 \\
\hline $\operatorname{Pr}>\mathrm{F}$ & NS & NS \\
\hline \multicolumn{3}{|c|}{ Chlorophyll index (SPADs) } \\
\hline $\mathrm{M1x}$ & 46.5 & 45.4 \\
\hline M1Z1 & 46.5 & 44.4 \\
\hline M2 & 47.1 & 44.9 \\
\hline M2 Z2 & 47.3 & 45.1 \\
\hline Control & 46.5 & 43.8 \\
\hline $\operatorname{Pr}>\mathrm{F}$ & NS & NS \\
\hline
\end{tabular}

${ }^{\mathrm{z}} \mathrm{M} 1=$ manure 12 ton/ha; M2 = manure 24 ton/ha; $\mathrm{Z1}=129 \mathrm{~kg} \mathrm{Zn}$ as $\mathrm{ZnSO}_{4} ; \mathrm{Z} 2=258 \mathrm{~kg} \mathrm{Zn}_{\text {as }} \mathrm{ZnSO}_{4}$ (manure had a pH of 7.8 and an electrical conductivity of 4.0 and contained $\approx 0.84 \%$ nitrogen, $0.18 \mathrm{P}_{2} \mathrm{O}_{5}$, and $1.19 \mathrm{~K}_{2} \mathrm{O}$ ).

${ }_{\mathrm{NS}}, *, * *=$ Nonsignificant, significant $(\operatorname{Pr}>\mathrm{F}=0.05)$, and highly significant $(\operatorname{Pr}>\mathrm{F}=0.01)$. from 46.5 to 47.3 in 2007 and from 46.8 to 45.4 in 2008. Manure treatments had the highest values, but differences were not significant.

Yield of whole nuts and kernel were affected by applied treatments (Table 4). In 2006, both treatments receiving manure outyielded the control treatment, but differences were not significant. In contrast, in 2007, the highest yield of nuts was obtained in the control treatment $\left(3852 \mathrm{~kg} \cdot \mathrm{ha}^{-1}\right)$, whereas other treatments had yields between 2891 and $3010 \mathrm{~kg} \cdot \mathrm{ha}^{-1}$. In 2008, the control treatment had the lowest yield, and it was significantly lower than M2Z2, which had the highest yield. Kernel yields and yield efficiency reflected overall yields. Differences in cumulative yields and cumulative efficiency were not significantly different, although control plots ranked highest in both. Alternate bearing intensity ranged from 0.15 to 0.7 . The control treatment had the highest alternate bearing intensity, but differences were not significant.

Nut filling and nut weight were unaffected by treatments (Table 5). Nut fill was excellent both years, over $61 \%$ in 2006 and over $62 \%$ in 2007 and 2008. Nut weight was larger

Table 4. Effect of manure and zinc (Zn) application on yield of nut and meat of 'Wichita' pecan trees. $^{z}$

\begin{tabular}{|c|c|c|c|}
\hline & 2006 & 2007 & 2008 \\
\hline Treatment $^{\mathrm{y}}$ & \multicolumn{3}{|c|}{ Yield of nut $\left(\mathrm{kg} \cdot \mathrm{ha^{-1 }}\right)$} \\
\hline M1 & 863 & $2,993 \mathrm{ab}$ & $1,844 \mathrm{~b}$ \\
\hline M1Z1 & 850 & $2,891 \mathrm{ab}$ & $1,676 \mathrm{a}$ \\
\hline M2 & & $3,086 \mathrm{ab}$ & $1,567 \mathrm{a}$ \\
\hline $\mathrm{M} 2 \mathrm{Z} 2$ & & $2,910 \mathrm{a}$ & $2,154 \mathrm{~b}$ \\
\hline Control & 597 & $3,852 \mathrm{~b}$ & $745 \mathrm{a}$ \\
\hline \multirow[t]{2}{*}{$\operatorname{Pr}>F^{x}$} & NS & $*$ & $*$ \\
\hline & \multicolumn{3}{|c|}{ Nut yield efficiency $\left(\mathrm{g} \cdot \mathrm{cm}^{-2}\right)$} \\
\hline M1 & 19.0 & $56.1 \mathrm{ab}$ & $29.9 \mathrm{ab}$ \\
\hline M1Z1 & 18.0 & $54.1 \mathrm{a}$ & $26.2 \mathrm{ab}$ \\
\hline M2 & & $62.3 \mathrm{ab}$ & $26.9 \mathrm{ab}$ \\
\hline M2Z2 & & $61.1 \mathrm{ab}$ & $37.9 \mathrm{~b}$ \\
\hline Control & 14.0 & $80.6 \mathrm{~b}$ & $12.8 \mathrm{a}$ \\
\hline \multirow[t]{2}{*}{$\operatorname{Pr}>F$} & NS & $*$ & $*$ \\
\hline & \multicolumn{3}{|c|}{ Yield of kernel $\left(\mathrm{kg} \cdot \mathrm{ha} \mathrm{a}^{-1}\right)$} \\
\hline M1 & 467 & $1,904 \mathrm{ab}$ & $1,155 \mathrm{al}$ \\
\hline M1Z1 & 448 & $1,794 \mathrm{ab}$ & $1,042 \mathrm{ab}$ \\
\hline M2 & & $1,960 \mathrm{ab}$ & $988 \mathrm{ab}$ \\
\hline M2Z2 & & $1,843 \mathrm{a}$ & $1,363 \mathrm{~b}$ \\
\hline Control & 322 & $2,417 \mathrm{~b}$ & $473 \mathrm{a}$ \\
\hline $\operatorname{Pr}>F$ & NS & $*$ & $*$ \\
\hline $\begin{array}{l}\text { Least significant } \\
\quad \text { difference }(0.05)\end{array}$ & & 583 & 747 \\
\hline
\end{tabular}

\begin{tabular}{lcc} 
& \multicolumn{2}{c}{ Alternate bearing intensity (I) } \\
\cline { 2 - 3 } & $2006-2007$ & $2007-2008$ \\
\hline M1 & 0.55 & $0.24 \mathrm{ab}$ \\
M1Z1 & 0.53 & $0.27 \mathrm{ab}$ \\
M2 & & $0.32 \mathrm{ab}$ \\
M2Z2 & & $0.15 \mathrm{a}$ \\
Control & 0.73 & $0.67 \mathrm{~b}$ \\
Pr $>$ F & NS & $* *$
\end{tabular}

${ }^{\mathrm{z}}$ Means followed by different letters are different at $P=0.05$ through analysis of variance testing. ${ }^{\mathrm{y}} \mathrm{M} 1=$ manure 12 ton/ha; M2 = manure 24 ton/ha; $\mathrm{Z1}=129 \mathrm{~kg} \mathrm{Zn}$ as $\mathrm{ZnSO}_{4} ; \mathrm{Z} 2=258 \mathrm{~kg} \mathrm{Zn}$ as $\mathrm{ZnSO}_{4}$ (manure had a $\mathrm{pH}$ of 7.8 and an electrical conductivity of 4.0 and contained $\approx 0.84 \%$ nitrogen, $0.18 \mathrm{P}_{2} \mathrm{O}_{5}, 1.19 \mathrm{~K}_{2} \mathrm{O}$ ).

${ }_{\mathrm{NS}}, *, * *=$ Nonsignificant, significant $(\mathrm{Pr}>\mathrm{F}=$ $0.05)$, and highly significant $(\operatorname{Pr}>\mathrm{F}=0.01)$. 
during 2006, when nut harvest was small. In 2007, nuts from the control treatments were lighter than nuts from other treatments, but differences were not significant.

The percentage of nuts exhibiting vivipary and the percentage of stick-tights were un-

Table 5. Effect of manure and zinc (Zn) application on nut quality of adult 'Wichita' pecan trees.

\begin{tabular}{|c|c|c|c|}
\hline \multirow[b]{2}{*}{ Treatment $^{2}$} & 2006 & 2007 & 2008 \\
\hline & \multicolumn{3}{|c|}{ Nut filling (kernel \%) } \\
\hline M1 & 61.9 & 63.6 & 62.7 \\
\hline M1Z1 & 61.4 & 62.2 & 62.2 \\
\hline M2 & & 63.3 & 62.8 \\
\hline M2Z2 & & 63.3 & 63.3 \\
\hline Control & 61.6 & 62.8 & 63.5 \\
\hline \multirow[t]{2}{*}{$\operatorname{Pr}>F$} & $\mathrm{NS}^{\mathrm{y}}$ & NS & NS \\
\hline & \multicolumn{3}{|c|}{ Nut weight $(g)$} \\
\hline M1 & 8.7 & 8.0 & 7.3 \\
\hline M1Z1 & 8.2 & 7.4 & 7.0 \\
\hline M2 & & 7.7 & 7.0 \\
\hline M2Z2 & & 7.9 & 7.2 \\
\hline Control & 8.6 & 7.5 & 7.2 \\
\hline \multirow[t]{2}{*}{$\operatorname{Pr}>\mathrm{F}$} & NS & NS & NS \\
\hline & \multicolumn{3}{|c|}{ Vivipary (\%) } \\
\hline M1 & 6.1 & 8.7 & 3.3 \\
\hline M1Z1 & 8.8 & 12.0 & 4.2 \\
\hline M2 & & 11.4 & 3.6 \\
\hline M2Z2 & & 11.2 & 3.8 \\
\hline Control & 6.0 & 12.7 & 3.8 \\
\hline \multirow[t]{2}{*}{$\operatorname{Pr}>F$} & NS & NS & NS \\
\hline & \multicolumn{3}{|c|}{ Stick tights (\%) } \\
\hline M1 & 8.8 & 4.8 & 4.9 \\
\hline M1Z1 & 7.3 & 4.8 & 3.7 \\
\hline M2 & & 4.0 & 4.4 \\
\hline M2Z2 & & 5.4 & 3.2 \\
\hline Control & 8.2 & 3.2 & 4.3 \\
\hline$\underline{\operatorname{Pr}>F}$ & NS & NS & NS \\
\hline \multicolumn{4}{|c|}{$\begin{array}{l}\mathrm{M} 1=\text { manure } 12 \text { ton } / \mathrm{ha} ; \mathrm{M} 2=\text { manure } 24 \mathrm{ton} / \mathrm{ha} \text {; } \\
\mathrm{Z} 1=129 \mathrm{~kg} \mathrm{Zn} \text { as } \mathrm{ZnSO}_{4} ; \mathrm{Z} 2=258 \mathrm{~kg} \mathrm{Zn} \text { as } \\
\mathrm{ZnSO}_{4} \text { (manure had a } \mathrm{pH} \text { of } 7.8 \text { and an electrical } \\
\text { conductivity of } 4.0 \text { and contained } \approx 0.84 \% \\
\left.\text { nitrogen, } 0.18 \mathrm{P}_{2} \mathrm{O}_{5}, 1.19 \mathrm{~K}_{2} \mathrm{O}\right) \text {. } \\
\mathrm{y}_{\mathrm{NS}}{ }^{*}, * *=\text { Nonsignificant, significant }(\mathrm{Pr}>\mathrm{F}= \\
0.05) \text {, and highly significant }(\mathrm{Pr}>\mathrm{F}=0.01) \text {. }\end{array}$} \\
\hline
\end{tabular}

affected by treatments (Table 5). The percentage of pregerminated (viviparous) nuts percent ranged from 6.0 to 12.7. Values were highest in 2007. Stick-tight percentages varied from $3.2 \%$ to $8.8 \%$, and the highest values occurred in 2006, the year of low nut production.

Leaf mineral composition of pecans was unaffected by manure or $\mathrm{Zn}$ applications in the first year of study but was affected during 2007 and 2008 (Table 6). In 2007, leaflet potassium levels were higher in the control and M1Z1 treatments. In 2008, 2 years after the start of the study, significant differences were found in foliar calcium $(\mathrm{Ca})$ and magnesium $(\mathrm{Mg})$ concentrations, which were highest in manure and manure plus $\mathrm{Zn}$ treatments. The control treatment had foliar $\mathrm{Ca}$ and $\mathrm{Mg}$ concentrations of $21.8 \mathrm{~g} \cdot \mathrm{kg}^{-1}$ and $\mathrm{g} \cdot \mathrm{kg}^{-1}$, respectively, compared with 25.8 $\mathrm{g} \cdot \mathrm{kg}^{-1}$ and $4.9 \mathrm{~g} \cdot \mathrm{kg}^{-1}$ in the M1Z1 treatment.

\section{Discussion}

The relatively low concentrations of foliar Zn during 2006 and 2007 did not cause visible deficiency symptoms in 'Wichita' pecan trees. Foliar $\mathrm{Zn}$ concentration ranged from 20 to 24,33 to 44 , and 46 to $62 \mathrm{ppm}$ during 2006, 2007, and 2008, respectively. Leaflet $\mathrm{Zn}$ concentrations generally were below the widely accepted critical level for the southeast conditions of $50 \mu \mathrm{g} \cdot \mathrm{g}^{-1}$ (Sparks, 1993, 1994; Wood, 2007) during the first 2 years of the study. These low levels of $\mathrm{Zn}$ apparently did not affect fruit set, yield, or quality of pecans in 2007 because a large crop with very high quality was produced.

In Georgia, high-yielding pecans (greater than $58 \mathrm{~kg}$ nuts per tree) had an average of $126 \mu \mathrm{g} \cdot \mathrm{g}^{-1} \mathrm{Zn}$ in leaves (Beverly and Worley, 1992), in Mexico $65 \mu \mathrm{g} \cdot \mathrm{g}^{-1}$ (Medina, 2004), and in the southwest United States $174 \mu \mathrm{g} \cdot \mathrm{g}^{-1}$ (Pond et al., 2006). Zinc critical levels have been established for pecans ranging from 20 to $60 \mu \mathrm{g} \cdot \mathrm{g}^{-1}$, and several authors have noticed no difference in tree growth development within this range (Lane et al., 1965; Obarr et al., 1978; Sparks, 1976; Storey et al., 1971; Worley et al., 1972). Seedlings of 'Curtis' grown in nutrient solution without $\mathrm{Zn}$ had 24 to $37 \mu \mathrm{g} \cdot \mathrm{g}^{-1}$ and seedlings showed mild $\mathrm{Zn}$ deficiency symptoms (Sparks, 1978). Pecans grown in sand culture under hydroponic conditions with a nutrient solution lacking $\mathrm{Zn}$ had intervenial necrosis in leaves with 7.2 $\mu \mathrm{g} \cdot \mathrm{g}^{-1}$, mottling at $9.8 \mu \mathrm{g} \cdot \mathrm{g}^{-1}$, and no symptoms in leaves with $11.2 \mu \mathrm{g} \cdot \mathrm{g}^{-1}$ (Kim et al., 2002).

Size of leaflets in this study were larger than those reported from 'Choctaw' pecan trees in spring flush shoots growing in Georgia, where leaflets had $18.5 \mathrm{~cm}^{2} /$ leaflet (Andersen and Brodbeck, 1988).

Published data regarding chlorophyll indices of pecan leaves are uncommon, but it is known that leaf chlorophyll content, stomatal conductance, and net photosynthesis are all positively related to leaf $\mathrm{Zn}$ concentration (Hu and Sparks, 1991). Chlorophyll content rose from 0.5 to $3.0 \mathrm{mg} \cdot \mathrm{g}^{-1}$ fresh leaflet in pecan as $\mathrm{Zn}$ leaflet concentration increased from 4 to $9 \mu \mathrm{g} \cdot \mathrm{g}^{-1}$ dry matter (Hu and Sparks, 1991). The lack of chlorophyll in Zn-deficient leaves is related with the characteristic interveinal chlorosis in $\mathrm{Zn}$ deficient pecan trees. Because the nut yield and quality from the trees in this study were relatively good, chlorophyll indices from these trees may be considered to represent acceptable readings for established 'Wichita' pecan trees in the irrigated southwestern United States. In several other crops, a SPAD index reading of 50 to 52 represented chlorophyll concentrations of 4 to $5 \mathrm{mg}$ of total chlorophyll per gram of (fresh weight) leaf (Uddling et al., 2007). Thus, in our study, $1 \mathrm{~g}$ of fresh leaflet was estimated to have

Table 6. Effect of manure and zinc ( $\mathrm{Zn})$ application on mineral composition of pecan 'Wichita' trees. ${ }^{\mathrm{z}}$

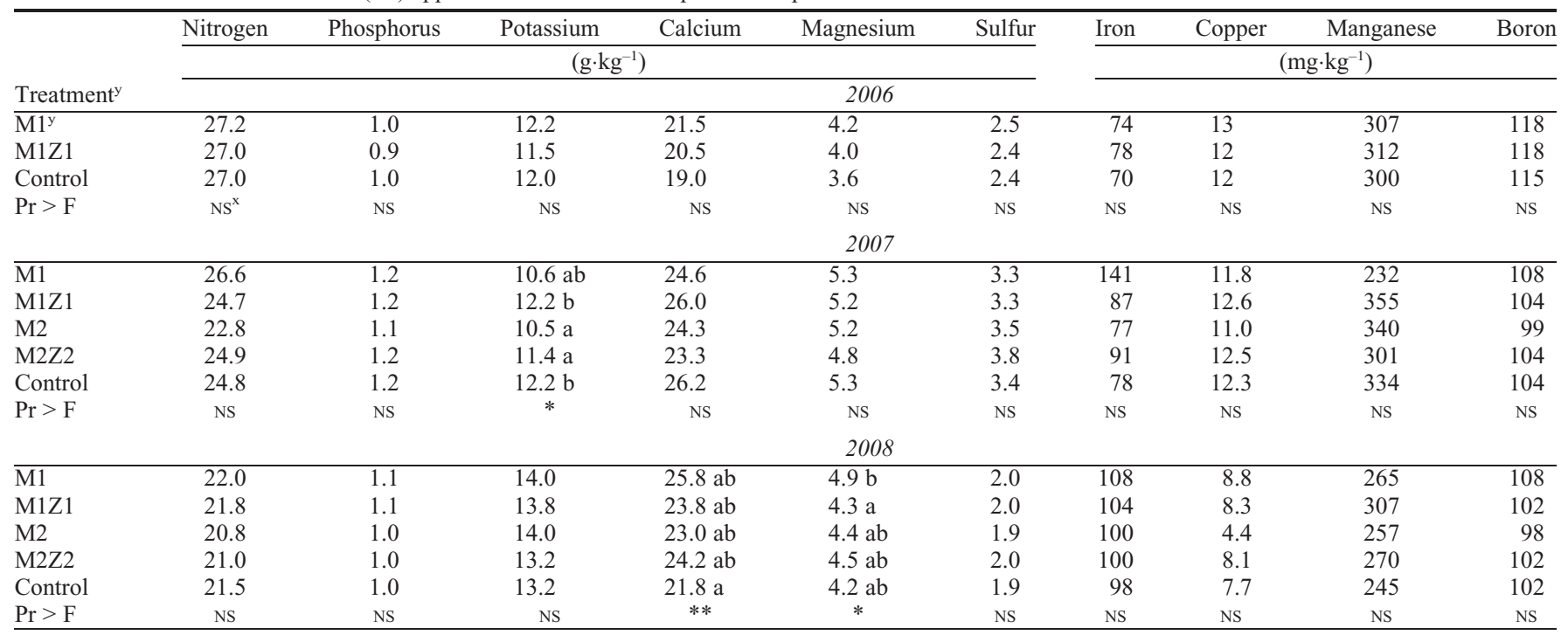

${ }^{\mathrm{z}}$ Means followed by different letters are different at $P=0.05$ through analysis of variance testing.

${ }^{\mathrm{y}} \mathrm{M} 1=$ manure $12 \mathrm{ton} / \mathrm{ha} ; \mathrm{M} 2=$ manure 24 ton/ha; $\mathrm{Z1}=129 \mathrm{~kg} \mathrm{Zn}$ as ZnSO $4 ; \mathrm{Z2}=258 \mathrm{~kg} \mathrm{Zn}$ as ZnSO 4 (manure had a pH of 7.8 and an electrical conductivity of 4.0 and contained $\approx 0.84 \%$ nitrogen, $0.18 \mathrm{P}_{2} \mathrm{O}_{5}, 1.19 \mathrm{~K}_{2} \mathrm{O}$ ).

${ }_{\mathrm{NS}}, *, * *=$ Nonsignificant, significant $(\mathrm{Pr}>\mathrm{F}=0.05)$, and highly significant $(\mathrm{Pr}>\mathrm{F}=0.01)$. 
contained $\approx 4$ to $5 \mathrm{mg}$ of chlorophyll. For comparison, healthy fresh 'Mohawk' leaflet had $185 \mathrm{mg}$ chlorophyll per leaflet (Andersen and Brodbeck, 1988). Hu and Sparks (1991) found that 'Stuart' fresh non-Zn-deficient leaflets contained $3.2 \mathrm{mg}$ of chlorophyll/g fresh leaves and $10 \mu \mathrm{g} \mathrm{Zn/g}$ in dry leaflets.

Yield was very low in 2006 but quite high in 2007. High nut yield coupled with low observed foliar Zn levels in 2007 suggests that the critical level of $50 \mu \mathrm{g} \cdot \mathrm{g}^{-1}$ may be too high. The fact that the highest yield in 2007 was in the control treatment could be a result of the very low yield in this treatment the previous year. This is apparent from the alternate bearing intensity, which is very high for this treatment (although not significantly different from other treatments). In other studies, 'Wichita' pecans have had lower alternate bearing intensities than those we observed in the control plots (Conner and Worley, 2000; Nunez, 2001).

A higher incidence of vivipary in 2007 than in 2006 could be the result of stress caused by the high crop load in 2007. In previous studies conducted in Arizona and Texas, it was reported that 'Wichita' exhibited increased vivipary when large crop load was present (Kilby and Gibson, 2000; Sparks et al., 1995).

Manure and $\mathrm{Zn}$ affected foliar $\mathrm{Zn}$ levels in the plant. These results agree with research with other crops: rice (Battacharyya et al., 2006); sorghum (Pinto et al., 2004); basil, chard, dill, and peppermint (Zheljazkov and Warman, 2004). Additionally, foliar Zn concentrations have also been increasing in control treatment since the beginning of the study. Possible explanations for this may be related to conversion of this orchard to "organic" production and a change from a traditional tillage system for eliminating weeds to mowing. A qualitative increase in activity of earthworms has been observed. Also, mycorrhizae activity is now apparent, because fruiting bodies of ectomycorrhizal Pisolithus tinctorius and Scleroderma bovista are now found in the orchard. Mycorrhizae can have a profound effect on uptake of soil-immobile nutrients such as Zn (Sharpe and Marx, 1986). A proliferation of feeder roots has been noted in the surface soil and in the leaf litter.

Application of manure and particularly manure plus $\mathrm{Zn}$ increased foliar $\mathrm{Zn}$ levels in pecan trees after 2 years of annual applications. Additional research on the effects of manure on $\mathrm{Zn}$ behavior would help provide understanding concerning the processes involved and management practices to enhance $\mathrm{Zn}$ uptake by pecan trees.

\section{Literature Cited}

Agbenin, J.O. 2003. Zinc fractions and solubility in a tropical semiarid soil under long-term cultivation. Biol. Fertil. Soils 37:83-89.

Alben, A.O. and H.E. Hammer. 1944. The effect of pecan rosette from applications of zinc sulfate, manure, sulfur on heavy textured alkaline soils. Proc. Amer. Soc. Hort. Sci. 45:27-32.

Andersen, P.C. and B.V. Brodbeck. 1988. Net Co2 assimilation and plant water relations charac- teristics of pecan growth flushes. J. Amer. Soc. Hort. Sci. 113:444-450.

Battacharyya, P., A. Chakraborty, K. Chakrabarti, S. Trypathy, and M.A. Powell. 2006. Copper and zinc uptake by rice and accumulation in soil amended with municipal solid waste compost. Environmental Geol. 49:1064 1070 .

Beverly, R.B. and R.E. Worley. 1992. Preliminary DRIS diagnostic norms for pecan. HortScience 27:271.

Bunluesin, S., P. Pokethitiyook, G. Lanza, J. Tyson, M. Kruatrachue, B. Xing, and S. Upatham. 2006. Influences of cadmium and zinc interactions and humic acid on metal accumulation in Ceratophyllum demersum. Water Air Soil Pollut. 180:225-235.

Chien, S.W.C., M.C. Wang, and C.C. Huang. 2006. Reactions of compost-derived humic substances with lead, copper, cadmium, and zinc. Chemosphere 64:1353-1361.

Conner, P.J. and R.E. Worley. 2000. Alternate bearing intensity of pecan cultivars. HortScience 35:1067-1069.

Essington, M.E. 2003. Soil and water chemistry. An integrative approach. CRC Press LLC, Boca Raton, FL.

Fenn, L.B., H.L. Malstrom, T. Riley, and G.L. Horst. 1990. Acidification of calcareous soils improves zinc-absorption of pecan trees. J. Amer. Soc. Hort. Sci. 115:741-744.

Foshee, W.G., W.D. Goff, K.M. Tilt, J.D. Williams, J.S. Bannon, and J.B. Witt. 1996. Organic mulches increase growth of young pecan trees. HortScience 31:811-812.

Hendricks, D.M. 1985. Arizona soils. College of Agric. Univ. of Arizona, Tucson, AZ.

Horowitz, W. 1980. Official methods of analysis of the Association of Analytical Chemist. Assn. Offic. Anal. Chemist. Washington DC.

$\mathrm{Hu}, \mathrm{H}$. and D. Sparks. 1991. Zinc-deficiency inhibits chlorophyll synthesis and gas-exchange in 'Stuart' pecan. HortScience 26:267-268.

Kilby, W.M. and R. Gibson. 2000. Performance of mature pecan varieties in the low desert of Pinal County 1997-1999. Citrus and deciduous fruit and nut research report. College of Agr. and Life Sci.

Kim, T., H.A. Mills, and H.Y. Wetzstein. 2002. Studies on the effect of zinc supply on growth and nutrient uptake in pecan. J. Plant Nutr. 25:1987-2000.

Lane, R., H.F. Perkins, and J.F.E. Johnstone. 1965. Studies on the relationship of calcium, zinc, and $\mathrm{pH}$ in pecan production. Proc. S.E. Pecan Growers Assn. 58:21-24.

Lindsay, W.L. 1972. Inorganic phase equilibria of micronutirents in soils, p. 41-57. In: Mordvet, J.J., P.M. Giordano, and W.L. Lindsay (eds.) Micronutrients in agriculture. Soil Sci. Soc. Amer. Madison, WI.

Malstrom, H.L. and L.B. Fenn. 1981. Uptake of zinc from calcareous soils by pecan (CaryaIllinoensis) trees. HortScience 16:414.

Medina, C. 2004. Normas DRIS preliminares para nogal pecanero. Terra 22:445-450.

Nunez, H. 2001. Desarrollo del nogal pecanero, p. 23-38. In: Duron, J. and H. Nunez (eds.). El nogal pecanero en Sonora. INIFAP, Hermosillo, Sonora.

Obarr, R.D., J.M. McBride, and K. Hanson. 1978. Pecan leaf sampling reveals shortages of fertilizer nutrients. Louisiana Agr. 21:6-7.

Olsen, S.R. and L.E. Sommers. 1982. Phosphorus, p. 403-430. In: Page, A.L. and R.H. Mller (eds.). Methods of soil analysis. Part 2. Chemical and microbiological. 2nd ed. Amer. Soc. Agron.-Soil Sci. Soc. Amer., Madison, WI.
Ozkutlu, F., B. Torun, and I. Cakmak. 2006. Effect of zinc humate on growth of soybean and wheat in zinc deficient calcareous soils. Commun. Soil Sci. Plant Anal. 37:2769-2778.

Pearce, S.C. and S. Dobersek-Urbanc. 1967. The measurement of irregularity in growth and cropping. J. Hort. Sci. 42:295-305.

Pinto, A.P., A.M. Mota, A.d. Varennes, and F.C. Pinto. 2004. Influence of organic matter on the uptake of cadmium, zinc, copper and iron by sorghum plants. Sci. Total Environ. 326: 239-245.

Pond, A., J. Walworth, W.M. Kilby, R. Gibson, R. Call, and H. Nunez. 2006. Leaf nutrient levels for pecans. HortScience 41:1339-1341.

Sadiq, M. 1991. Solubility and speciation of zinc in calcareous soils. Water, Air, and Pollution 57:411-421.

Sharpe, R.R. and D.H. Marx. 1986. Influence of soil $\mathrm{pH}$ and Pisolithus tinctorius ectomycorrhizae on growth and nutrient-uptake of pecan seedlings. HortScience 21:1388-1390.

Smith, M.W., J.B. Storey, P.N. Westfall, and W.B. Anderson. 1980. Zinc and sulfur content in pecan leaflets as affected by application of sulfur and zinc to calcareous soils. HortScience 15:77-78.

Sparks, D. 1976. Zinc nutrition and the pecan. A review. Pecan South. 3:304-334.

Sparks, D. 1978. Nutrient concentrations of pecan leaves associated with deficiency symptoms and normal growth. HortScience 13:256-257.

Sparks, D. 1993. Threshold leaf Levels of zinc that influence nut yield and vegetative growth in pecan. HortScience 28:1100-1102.

Sparks, D. 1994. Leaf zinc for maximum yield, growth in pecan. Pecan South. 27:19-24.

Sparks, D., W. Reid, I.E. Yates, M.W. Smith, and T.G. Stevenson. 1995. Fruiting stress induces shuck decline and premature germination in pecan. J. Amer. Soc. Hort. Sci. 120:43-53.

Storey, J.B., G. Wadsworth, M. Smith, and D. Westfall. 1971. Pecan zinc nutrition. Proc. S.E. Pecan Growers Assn. 64:87-91.

Tahboub, M.B., W.C. Lindemann, and L. Murray. 2007. Nutrient availability in soil amended with pecan wood chips. HortScience 42:339-343.

Tahboub, M.B., W.C. Lindemann, and L. Murray. 2008. Chemical and physical properties of soil amended with pecan wood chips. HortScience 43:891-896

Uddling, J., J. Gelang-Alfredson, and K. Piikki. 2007. Evaluating the relationship between chlorophyll concentration and SPAD-502 chlorophyll meter readings. Photosynth. Res. 91: 37-46.

Udo, E.J., H.L. Bohn, and T.C. Tucker. 1970. Zinc adsorption by calcareous soils. Soil Sci. Soc. Amer. Proc. 34:405-407.

Warwick, P., A. Hall, V. Pashley, J.V. der Lee, and A. Maes. 1998. Zinc and cadmium mobility in sand: Effects of $\mathrm{pH}$, speciation, cation exchange capacity, humic acid and metal ions. Chemosphere 36:2283-2290

Wood, B. 2007. Correction of zinc deficiency in pecan by soil banding. HortScience 42:1554 1558.

Worley, R.E., S.A. Harmon, and R.L. Carter. 1972. Correlation among growth, yield, and nutritional factors for pecan (Carya-Illinoesis W CV Stuart)-Correlations with yield, quality, and terminal shoot growth. J. Amer. Soc. Hort. Sci. 97:514

Zheljazkov, V.D. and P.R. Warman. 2004. Phytoavailability and fractionation of copper, manganese, and zinc in soil following application of two compost for four crops. Environ. Pollut. 131:187-195. 